\title{
PENGEMBANGAN MODEL PEMBELAJARAN MEMBACA BERBASIS PERMAINAN BAGI PEMBENTUKAN KARAKTER SISWA SEKOLAH DASAR DI KOTA MAKASSAR
}

\author{
Muh. Amin \\ SMA Negri 1 Sungguminasa Kabupaten Gowa, Sulawesi Selatan \\ 195811081984111002 \\ aninnyampa58@yahoo.com
}

\begin{abstract}
Abstrak
Penelitian pengembangan (Research \& Development) ini terdapat tahap perancangan, pengembangan, dan penyebarluasan. Data penelitian ini mencakup data hasil uji ahli, uji praktisi, dan hasil uji lapangan. Analisis data menggunakan teknik deskripsi kualitatif dan kuantitatif. Tujuan penelitian menghasilkan produk model PMBP-PK yang berkaitan dengan perencanaan pembelajaran (silabus, RPP, LKS, dan Bahan ajar) dan Keterlaksanaan pembelajaran. Hasil penelitian berdasarkan uji ahli dan praktisi terhadap kelayakan isi dan validasi isi silabus dinyatakan layak. Persentase keefektifan struktur dan kriteria silabus dinyatakan efektif karena mencapai 79,17\%. Hasil uji ahli dan praktisi terhadap kelayakan dan validasi RPP dinyatakan layak dan valid. Persentase kesesuaian struktur dan kriteria mencapai tingkat kesesuaian 3,68 atau mencapai 92\%. Hasil uji kelayakan produk LKS dinyatakan layak berbadasarkan hasil validator ahli dan praktisi. Persentase kesesuaian LKS pada kategori sesuai yaitu $87,5 \%$. Hasil uji ahli dan praktisi terhadap bahan ajar dinyatakan layak, valid, dan sesuai kategori (sangat sesuai) yaitu 3,78 atau mencapai 94,5\%. Hasil uji ahli penilaian membaca dari permainan (bisik berantai, baca lakukan, meloncat bulatan kata, dan kata dari wacana) mencapai kategori sesuai $(70,83 \%)$ dan hasil uji praktisi sangat efektif $(97,92 \%)$. Hasil uji coba lapangan model pembelajaran membaca secara keseluruhan berada pada kategori baik. Temuan penelitian terhadap produk model PMBP-PK, (1) perencanaan pembelajaran, Keterlaksanaan pembelajaran, dan penilaian dinyatakan valid, efektif, dan praktis, (2) permainan dalam pembelajaran membaca sesuai dengan tingkat usia siswa kelas II SD, dan (3) pembentukan karakter sesuai permainan dalam pembelajaran pada kategori positif/baik.
\end{abstract}

Kata Kunci: model PMBP-PK, membaca, permainan, karakter

\begin{abstract}
Research development is there stage of design, development, and dissemination. This research data includes expert test result data, practitioner test, and field test result. Data analysis uses qualitative and quantitative description techniques. The objective of the research is to produce the model product of PMBP-PK relating to learning planning (syllabus, RPP, LKS, and teaching materials) and the implementation of learning. The results of the research based on expert and practitioner's test on the feasibility of the content and validation of syllabus content is declared feasible. Percentage of structure effectiveness and syllabus criteria are effective as they reach $79.17 \%$. Expert and practitioner test results on the feasibility and validation of RPP are eligible and valid. Percentage of suitability of structures and criteria reached the level of
\end{abstract}


conformity of 3.68 or $92 \%$. The result of feasibility test of LKS product is feasible based on expert and practitioner validator result. The percentage of conformity of LKS in the appropriate category is $87.5 \%$. Expert and practitioner test results on teaching materials are declared eligible, valid, and appropriate (very suitable) category that is 3.78 or reach $94.5 \%$. The result of the expert assessment of the reading of the game (whispered chain, read do, jumping word sphere, and word of discourse) reached the appropriate category (70.83\%) and the practitioner's test result is very effective (97.92\%). The results of field trials learning model reading as a whole are in good category. Research findings on PMBP-PK model products, (1) learning planning, implementation of learning, and assessment stated valid, effective, and practical, (2) games in reading learning according to the age level of second grade students of elementary school, and (3) according to the game in learning in positive I good category.

\section{KeywBords: PMBP-PK model, reading, game, character}

\section{PENDAHULUAN}

Depdiknas (2006:1) menyatakan bahwa KTSP SD/MI kurikulum disusun agar dapat memberi kesempatan kepada siswa untuk: 1) belajar untuk bermain dan bertakwa kepada Tuhan Yang Maha Esa, 2) belajar untuk memahami dan menghayati, 3) belajar untuk mampu melaksanakan secara efektif, 4) belajar untuk hidup bersama dan berguna untuk orang lain, dan 5) belajar untuk membangun dan menemukan jati diri melalui proses belajar yang aktif, kreatif, efektif, dan menyenangkan. Kurikulum merupakan pegangan bagi pelaksana pembelajaran di sekolah, tetapi merupakan tugas dan tanggung jawab guru untuk menjabarkannya (Nana Syaodih dalam Hamid, 2012:45).

Pembelajaran bahasa Indonesia dalam Kurikulum Sekolah Dasar, bertujuan untuk: 1) berkomunikasi secara efektif dan efisien sesuai dengan etika yang berlaku; 2) bangga menggunakan bahasa Indonesia sebagai bahasa persatuan dan bahasa Negara; 3) menggunakannya dengan tepat dan kreatif untuk berbagai tujuan; 3) meningkatkan kemampuan intelektual, serta kematangan emosional dan sosial; 4) memanfaatkan karya sastra untuk memperluas wawasan, budi pekerti, serta meningkatkan kemampuan berbahasa; 5) menghargai sastra Indonesia sebagai hasanah budaya dan intelektual manusia Indonesia (Jaya, 2010).

Kenyataan menunjukkan bahwa pembelajaran membaca selama ini belum menggembirakan. Mereka lebih senang memilih bermain, meninggalkan tugas membaca yang disuguhkan guru. Sejalan dengan pernyataan Wamendikbud (Musliar Kasim) pada media Cakrawala (6 November 2012) merasa prihatin terhadap minat baca anak-anak di tanah air masih rendah. Kalau anak-anak disuruh membaca pasti tidak betah, kecuali yang belajarnya sudah baik, tetapi kalau menonton televisi, dari pagi sampai siang akan betah bahkan makan saja bisa dilupa. Ismail (1998) mengemukakan, bahwa bangsa kita sudah menjadi bangsa yang "rabun membaca buku dan sangat merosot kemampuannya dalam mengemukakan pikiran dalam bentuk karangan." 
Bukti empirik hasil pengamatan berupa hasil pembelajaran melalui dokumen sekolah dan hasil wawancara kepada guru kelas II Sekolah Dasar Inpres Bertingkat Mamajang, SD Inpres Perumnas I di Kota Makassar, dan Sekolah Dasar Negeri Kapota Yuda Kota Makassar tahun pelajaran 20122013 menunjukkan bahwa siswa belum mampu memahami isi teks bacaan, kurang berminat, dan kurang termotivasi membaca. Hal ini disebabkan dari siswa kelas II Sekolah Dasar yang berusia antara 7-8 tahun tingkat bermainnya sangat tinggi. Oleh karena itu, pembelajaran membaca pada penelitian ini dikemas dalam permainan yang dapat menumbuhkan minat dan motivasi siswa yang dapat membentuk karakter yang lebih baik.

Implementasi pembelajaran nilai karakter tidak mudah diwujudkan. Kurang berhasilnya pembelajaran terhadap pengintegrasian nilai-nilai karakter pada pembelajaran di Sekolah Dasar, maka perlu dilaksanakan penelitian yang berkaitan dengan hal itu. Penelitian yang dimaksud adalah "Pengembangan Model Pembelajaran Membaca Berbasis Permainan Pembentukan Karakter (PMBP-PK) Siswa Kelas II Sekolah Dasar".

Model PMBP-PK yang valid, efektif, dan praktis bagi siswa kelas II Sekolah Dasar. Membantu siswa memiliki keterampilan membaca yang lebih baik, menarik, meningkatkan pemahaman isi bacaan, minat dan motivasi membaca.

\section{TINJAUAN PUSTAKA}

Mc. Neil (Brown, 1987:22) menguraikan LAD itu terdiri atas empat bakat bahasa, yakni: 1) Kemampuan untuk membedakan bunyi bahasa dengan bunyi-bunyi yang lain. 2) Kemampuan mengorganisasikan peristiwa bahasa ke dalam variasi yang beragam. 3) Pengetahuan adanya sistem bahasa. 4) Kemampuan untuk mengevaluasi sistem perkembangan bahasa. Chomsky dan James Deez, berpandangan bahwa setiap manusia memiliki kesiapan alamiah untuk belajar bahasa. Manusia lahir dibekali oleh Sang Pencipta dengan peranti pemerolehan bahasa atau LAD (Language Acquisition Device).

Dalam teori Psikologi, Jean Piaget (1896-1980) dalam buku Life Span Development: Perkembangan Masa Hidup, John W. Santrok pada tahun 2002, dinyatakan bahwa anak dapat membangun secara aktif pada dunia kognitif, menyesuaikan pemikiran untuk menguasai gagasan baru, karena informasi tambahan akan menambah pemahaman mereka.

http://www.psikologizone.com/teorikognitif-psikologi-perkembangan-jeanpiaget/06511234 diakses 6 Mei 2013.

Intelegensi menurut Piaget: 1) Intelegensi adalah suatu fungsi kehidupan yang mendasar yang membantu organisme untuk menyesuaikan diri dengan lingkungannya. 2) Satu-satunya tujuan aktivitas intelektual adalah untuk mencapai keseimbangan. 3) Lingkungan itu adalah suatu tempat yang menarik dan penuh dengan pelbagai rangsangan baru yang tidak segera dapat dipahami anak yang aktif dan penuh rasa ingin tahu. 4) Intelegensi adalah suatu atribut yang sangat majemuk, yang terdiri atas tiga komponen yang saling 
berhubungan yaitu isi intelegensi, struktur kognitif, dan fungsi intelektual.

\section{a. Hakikat Membaca}

1) Pengertian Membaca

Dawkins dalam Abbas (1992:29), adalah menyuarakan lambang-lambang atau huruf yang tercetak secara benar. Batasan ini relevan dengan tingkat membaca permulaan yang lazim dilakukan membaca nyaring. Smith (1982:28) mengatakan bahwa membaca adalah memberi makna dan mengambil makna dari tuturan tertulis yang dibaca (Reading is the bringing or meaning and the getting of meaning from the printed pages). Richards, Platt, dan Weber (1987:280) mengatakan bahwa membaca adalah pengucapan kata-kata dan pemerolehan arti dari lambang cetakan (Wiryodijoyo, 1989:1-2).

Widyamartaya

(1992:137-138) mengemukakan bahwa membaca adalah ikhtisar yang terus-menerus untuk mengembangkan diri. Syafi'ie (1996: 24-25) mendefinisikan membaca adalah kegiatan kompleks yang mencakup berbagai aspek baik secara fisik maupun mental, yang di dalamnya meliputi aspek sensori, persepsi, sekuensi eksperimental, dan asosiasi. Shriver (2007) mengatakan membaca adalah cara seseorang memeroleh informasi dari huruf-huruf dan kata-kata yang tertulis. McWhorter (1992: 4) mengemukakan bahwa seorang pembaca yang memiliki comprehension skills yang baik dalam membaca: 1) Menetapkan tujuan dan batas waktu sesi membaca. 2) Memiliki pertanyaan tertentu dalam pikirannya ketika membaca. 3) Sebelum mulai membaca ia menghabiskan beberapa menit melihat tugas yang berkaitan bacaan yang dibacanya. 4) Ketika membaca, dia mencoba memprediksi atau mengantisipasi apa yang penulis katakan selanjutnya. 5) Ketika ia selesai membaca, ia menghabiskan beberapa menit untuk meninjau kembali apa yang ia telah dibaca. 6) Ia memerhatikan kata-kata dan frasa yang memberikan sinyal perubahan. 7) Dia dapat membedakan hal-hal penting dan kurang penting ketika ia membaca. 8) Ketika ia bertemu dengan kata yang ia tidak tahu maknanya, ia mencoba untuk menentukan maknanya kata itu digunakan dalam kalimat. 9) Dia secara teratur menggarisbawahi informasi penting dan menggunakan catatan ringkas serta notasi marjinal untuk mengidentifikasi informasi penting. 10) Ketika membaca bahan bacaan bukan buku teks, dia mencoba untuk menentukan tujuan penulis dalam menulis bahan bacaan tersebut.

Crawley dan Mountain (1995) menyatakan bahwa membaca pada hakikatnya adalah suatu tindakan yang rumit yang melibatkan banyak hal, tidak sekadar melafalkan tulisan, tetapi juga melibatkan aktivitas visual, berpikir, psikolinguistik, dan metakognitif. Muji (2011:8) menyatakan bahwa membaca salah satu jenis kemampuan berbahasa yang bersifat reseptif. Syafi'ie (1999) menyebut ada tiga istilah yang sering digunakan sebagai komponen dasar proses membaca, yaitu recoding, decoding, dan meaning. Recoding merujuk pada kata-kata dan kalimat, kemudian mengasosiasikan dengan bunyinya sesuai dengan sistem tulisan yang digunakan. Proses decoding (penyandian) merujuk pada proses penerjemahan rangkaian grafis ke dalam kata-kata. Proses meaning lebih ditekankan di kelas tinggi SD.

Pemahaman makna berlangsung melalui berbagai tingkat, mulai dari 
tingkat pemahaman literal sampai pemahaman yang interpretatif, kreatif, dan evaluatif (Syafi'ie, 1999:17). Membaca merupakan gabungan proses perseptual dan kognitif. Crawley dan Mountain (1995), menyatakan bahwa membaca pada hakikatnya adalah suatu tindakan yang rumit yang melibatkan banyak hal (seperti melibatkan proses visual, berpikir, psikolinguistik, dan metakognitif). Smith (1982:29) mengemukakan bahwa kegiatan membaca, paling tidak diperlukan dua macam informasi, yaitu informasi yang diterima oleh otak si pembaca dari bahan yang dibaca melalui indera matanya dan informasi nonvisual yaitu informasi yang sudah ada pada benak pembaca.

\section{2) Tujuan Membaca}

Nurhadi

(1987:134-135)

menyimpulkan pendapat para ahli berdasarkan penelitian yang telah dilaksanakan bahwa: 1) Gerakan bola mata waktu membaca berubah kecepatannya sejalan dengan perubahan tujuan membacanya; 2) Kemampuan seseorang dalam memahami bahan bacaan secara nyata dipengaruhi oleh tujuan membacanya; 3) Tujuan membaca yang terumuskan secara jelas akan memengaruhi pemerolehan pemahaman bacaan; 4) Seseorang yang mempunyai daya baca tinggi, mampu memanfaatkan teknik membaca yang bervariasi sejalan dengan tujuan membaca yang dicapainya. Waples (1967) dalam Nurhadi (1987) menyatakan tujuan membaca meliputi: 1) memeroleh sesuatu yang bersifat praktis; 2) ingin mendapat rasa lebih (self image) dibandingkan orang lain dalam lingkungan pergaulannya; 3) memperkuat nilai pribadi/keyakinan, 4) mengganti pengalaman esketika yang usang; dan 5) menghindarkan diri dari kesulitan, ketakutan, atau penyakit tertentu.

Oka (1983:70) mengatakan tujuan pokok pembelajaran membaca agar siswa memiliki: 1) kemampuan yang baik dalam membaca yang tersurat, tersirat, dan tersorot dari macam-macam tuturan tertulis yang dibacanya; 2) pengetahuan yang sahih tentang nilai dan fungsi membaca dan teknik membaca guna mencapai tujuan tertentu; dan (3) sikap positif terhadap membaca dan belajar membaca. Wiryodijoyo (1989:56-58) mengemukakan bahwa, tujuan membaca berdasarkan materi bacaan dibedakan menjadi lima, yaitu 1) membaca untuk kesenangan, 2) membaca untuk penerapan praktis, 3) membaca untuk mencari informasi khusus, 4) membaca untuk mendapatkan gambaran umum, 5) membaca untuk mengpenilaian secara kritis. Hanafie (1998) mengemukakan bahwa kemampuan membaca mempunyai beberapa tujuan, di antaranya; 1) memeroleh rincian atau fakta-fakta, 2) memeroleh ide atau gagasan utama yang terdapat dalam bacaan, 3) mengetahui urutan organisasi teks, 4) menyimpulkan isi bacaan dan membaca infrensi, 5) mengklasifikasi, dan 6) menilai latar belakang penulis dan isi tulisannya.

\section{b. Keterlaksanaan dan Kegiatan Pembelajaran Membaca}

1) Keterlaksanaan Pembelajaran Membaca 
Muji (2011:32) mengutip pendapat Burns, dkk. menyatakan bahwa siswa terdorong memahami keseluruhan materi jika guru membiasakan membaca dengan tiga tahapan kegiatan, yaitu prabaca, saat baca, dan pascabaca. Rahim (2011:99-109) mengemukakan Keterlaksanaan pembelajaran membaca dibagi dalam tiga tahap, yaitu: 1) kegiatan prabaca adalah pembelajaran yang dilakukan sebelum siswa melakukan kegiatan membaca; 2) kegiatan saat baca (during reading) adalah strategi yang digunakan untuk meningkatkan pemahaman siswa; 3) kegiatan pascabaca digunakan untuk memadukan informasi baru yang dibacanya ke dalam skemata yang telah dimilikinya sehingga diperoleh tingkat pemahaman yang lebih tinggi.

Oka (1983) berpendapat bahwa pembelajaran membaca dapat dilakukan dengan cara: 1) pembelajaran membaca permulaan yang bertujuan membina dasar mekanisme membaca; 2) pembelajaran membaca nyaring merupakan lanjutan membaca permulaan atau membaca tingkat lanjut; 3) pembelajaran membaca dalam hati bertujuan membina siswa membaca tanpa bersuara dan mampu memahami isi bacaan; 4) pembelajaran membaca pemahaman hampir sama dengan membaca dalam hati; 5) pembelajaran membaca bahasa bertujuan membina kemampuan bahasa siswa; dan 6) pembelajaran membaca teknik memusatkan perhatian pada kemampuan siswa menguasai teknik membaca yang tepat.

2) Kegiatan Keterlaksanaan Membaca Membaca merupakan proses yang kompleks dan melibatkan fisik dan mental. Nuttall dan Rustono (2010) menjelaskan makna yang terdapat dalam suatu bacaan tidaklah terpahami begitu saja oleh seseorang. Abbas (1992:30) mengutip pernyataan Goodman yang menyatakan membaca adalah suatu proses yang rumit, pembaca harus melakukan rekonstruksi dalam tingkat tertentu terhadap pesan yang dituangkan oleh pengarang dalam bahasa tulis. Syafi'ie (1999:44) menyatakan bahwa untuk memahami bacaan, pembaca terlebih dahulu memahami kata-kata dan kalimat yang dihadapinya melalui kegiatan proses asosiasi dan proses eksperimental.

Oka (1983:74) menyatakan bahwa, untuk memahami suatu bacaan diperlukan aspek, yaitu: 1) kemampuan menguasai kosakata, 2) kemampuan menafsirkan buah pikiran yang ada dalam frase, kalimat, dan paragraf, 3) kemampuan menangkap ide pokok bacaan dan ide penunjangnya, 4) kemampuan menangkap isi bacaan, 5) kemampuan menangkap urutan peristiwa dalam bacaan, 6) kemampuan menangkap maksud pengarang, 7) kemampuan menilai dan mengomentari bacaan secara kritis, 8) kemampuan mengikuti yang digariskan dalam bacaan, 9) kemampuan mengingat masalah pokok dalam suatu bacaan, dan 10) kemampuan mengatur pemahaman. Agar hasil membaca dapat tercapai secara maksimal, pembaca harus menguasai kegiatan-kegiatan dalam proses membaca tersebut (Syafi'ie, 1999: 46). Oleh sebab itu, guru-guru SD memegang peranan penting dalam membimbing para siswa mampu menguasai kegiatan dalam proses membaca dengan baik. 


\section{c. Faktor yang Memengaruhi Kemampuan Membaca}

1) Faktor Fisiologis

Faktor fisiologis mencakup

kesehatan fisik, pertimbangan neurologis, dan jenis kelamin. Keterbatasan neurologis (misalnya berbagai cacat otak) dan kekurangmatangan fisik merupakan salah satu faktor yang dapat menyebabkan anak gagal dalam meningkatkan kemampuan membaca. Rahim (2003:35) menyatakan pula bahwa walaupun tidak mempunyai gangguan pada alat penglihatan, beberapa anak mengalami kesukaran membaca. Hal itu dapat terjadi karena belum berkembangnya kemampuan membedakan simbol-simbol cetakan, seperti huruf-huruf, angka-angka, dan kata-kata, misalnya anak belum bisa membedakan b, p, dan d.

\section{2) Faktor Intelektual}

$$
\text { Istilah intelegensi dapat }
$$

didefinisikan sebagai suatu bentuk berpikir yang terdiri atas pemahaman yang esensial tentang situasi yang diberikan dan merespon secara tepat. Rahim (2003:35) menutip pendapat Wechster (1980) yang menyatakan bahwa intelegensi adalah kemampuan global individu untuk bertindak sesuai dengan tujuan, berpikir rasional, dan berbuat secara efektif terhadap lingkungan.

\section{3) Faktor Lingkungan}

Faktor lingkungan juga memengaruhi kemajuan kemampuan membaca anak. Faktor lingkungan dapat membentuk pribadi, sikap, nilai, dan kemampuan bahasa anak. Kondisi di rumah memengaruhi pribadi dan penyesuaian diri anak dalam masyarakat yang dapat membantu anak, tetapi dapat juga menghalangi anak membaca. Rumah juga berpengaruh pada sikap anak terhadap membaca. Orangtua yang gemar membaca, memiliki koleksi buku, menghargai membaca, dan senang membacakan cerita kepada anak-anak mereka umumnya menghasilkan anak yang senang membaca.

4) Faktor Psikologis

Motivasi adalah faktor kunci belajar membaca dan kemajuan kemampuan membaca permulaan bagi anak. Crawley dan Mountain (1995:40) mengemukakan bahwa motivasi ialah sesuatu yang mendorong seseorang belajar atau melakukan kegiatan yang memengaruhi minat dan hasil belajar siswa. Ada lima ciri siswa yang bermotivasi, yakni 1) persepsinya terhadap waktu; 2) keterbukaannya pada pengalaman; 3) konsepsinya tentang diri sendiri; 4) nilai-nilai; siswa cenderung menilai hal-hal yang abstrak dan teoretis; dan 5) toleransi dan ambiguitas.

Minat baca ialah keinginan yang kuat disertai usaha seseorang untuk membaca. Frymier (dalam Crawlye dan Mountain, 1995) ada tujuh faktor yang memengaruhi perkembangan minat anak, yaitu: 1) pengalaman sebelumnya; 2) konsepsinya tentang diri; 3) nilainilai; 4) mata pelajaran yang bermakna; 5) tingkat keterlibatan tekanan; 6) kekompleksitasan materi pelajaran; dan 7) intelektual dan fleksibel secara psikologis. 


\section{d. Konsep Permainan}

1) Pengertian Bermain atau Permainan Ahli psikologi, Hurlock (dalam Wibowo, 2008:2) berpendapat bahwa ada lima faktor yang dapat memengaruhi permainan anak usia dini, yaitu: 1) Kesehatan (anak yang sehat mempunyai banyak energi bermain dibandingkan anak yang kurang sehat). 2) Intelegensi (yang cerdas lebih aktif dan lebih menyenangi permainan yang bersifat intelektual, permainan yang banyak merangsang daya berpikir). 3) Jenis kelamin (anak perempuan lebih sedikit melakukan permainan yang menghabiskan banyak energi dibandingkan anak laki-laki). 4) Lingkungan (anak yang dibesarkan di lungkungan yang kurang menyediakan peralatan, waktu, dan ruang bermain menimbulkan aktivitas bermain anak berkurang). 5) Status sosial ekonomi (anak yang dibesarkan di lingkungan keluarga yang status sosial ekonominya tinggi, lebih banyak tersedia alat-alat permainan yang lengkap dibandingkan anak-anak yang dibesarkan di keluarga yang status ekonominya rendah).

Montessori (dalam Sudono, 2000:3), perencanaan dan persiapan lingkungan belajar anak harus dirancang dengan saksama sehingga segala sesuatu merupakan kesempatan belajar yang sangat menyenangkan bagi anak itu sendiri. Mayke (dalam Sudono, 1995) dalam bukunya "Bermain dan Permainan" menyatakan bahwa belajar dengan bermain memberi kesempatan kepada anak untuk memanipulasi, mengulang-ulang, menemukan sendiri, mengeksplorasi, mempraktikkan, dan mendapatkan bermacam-macam konsep.
2) Jenis Permainan dalam Pembelajaran Membaca di Sekolah Dasar

Keterlaksanaan permainan bahasa terdapat kelebihan dan kekurangan. Soeparno (dalam Djuanda, 2006:95) menyebutkan kelebihan dan kelemahan permainan bahasa sebagai berikut: 1) Kelebihan permainan bahasa, yaitu permainan bahasa sebagai metode pembelajaran dapat meningkatkan keaktifan siswa dalam proses belajarmengajar; aktivitas yang dilakukan siswa bukan saja fisik tetapi juga mental; dapat membangkitkan motivasi siswa dalam belajar; dapat memupuk rasa solidaritas dan kerjasama; dengan permaian materi lebih mengesankan sehingga sukar dilupakan. 2) Kelemahan permainan bahasa, yaitu bila jumlah siswa terlalu banyak melibatkan seluruh siswa dalam permainan, tidak semua materi dapat dilaksanakan melalui permainan, banyak mengandung unsur spekulasi sehingga sulit dijadikan ukuran yang terpercaya.

Ada empat jenis permainan yang berkaitan kebutuhan penelitian dan sesuai dengan tingkat perkembangan siswa kelas II di Sekolah Dasar. Keempat contoh permainan yang dapat dijadikan sebagai materi penelitian pengembangan model membaca pada siswa kelas II di Sekolah Dasar, yaitu: 1) Bisik Berantai; 2) baca lakukan; 3) meloncat bulatan kata; dan 4) kata dari wacana.

3) Bermain sebagai Pembelajaran Jill Hadfield (1984:5) menyatakan A game is an activity with rules, a goal and an element of fun. One of the most 
important reasons for using games is simply that they are immensely enjoyable for both teacher and student. Mengajak siswa bermain sambil belajar ternyata memberi banyak manfaat bagi guru dan siswa.

Manfaat permainan bagi guru, yaitu: 1) Guru lebih mudah memberikan penjelasan suatu materi pelajaran, bila diterapkan dalam permainan; 2) Guru dapat membuat suasana kelas menjadi lebih hidup; dan 3) Guru mendapatkan prestasi tersendiri di tempat guru membuat semua siswanya berpartisipasi aktif selama proses belajarmengajar di kelas. Sedangkan manfaat permainan bagi siswa, yaitu: 1) Siswa lebih mudah memahami materi pelajaran yang dipelajari karena disajikan dalam permainan; 2) Permainan dapat mengurangi kebosanan siswa belajar di dalam kelas; 3) Siswa lebih mudah dan cepat mengingat materi pelajaran; 4) Siswa menjadi aktif di kelas; dan 5) Siswa memiliki rasa solidaritas dan sportivitas di kalangan teman-temannya.

\section{4) Bermain sebagai Pembentukan} Karakter

Berdasarkan kebiasaan baik, maka indikator karakter: 1) kejujuran (tidak berbohong, tidak mengambil bukan miliknya, tidak menyontek dalam ulangan/ujian); 2) tanggung jawab (berani mengakui kesalahan, menjalankan kewajiban dengan baik); 3) semangat belajar (berani bertanya, berani mempertanyakan, senang mencari cara-cara baru, senang mencari pengalaman baru, senang menambah pengetahuan); 4) disiplin diri (datang tepat waktu, menepati janji, menaati peraturan/tata tertib, sopan dan santun dalam tindakan dan ucapan); 5) kegigihan (berusaha melakukan yang terbaik, tidak mudah menyerah dan bekerja keras); 6) Apersepsi terhadap kebhinekaan (menghargai pendapat yang berbeda, berinteraksi dengan orang dari berbagai latar belakang budaya dan tidak mau menang sendiri); 7) semangat berkontribusi (senang menolong orang lain, senang berbagi, dermawan, dan senang melakukan kegiatan social/relawan); (8) Optimisme (tidak mudah mengeluh, menunjukkan semangat dalam kegiatan).

\section{e. Konsep Karakter}

\section{1) Pengertian Karakter}

Istilah karakter sebenarnya memiliki arti yang seragam. Secara harfiah, "character" (latin) berarti instrument of marking, "charessein" (Perancis) berarti to engrove (mengukir). Pusat Bahasa (2008:317) karakter sama dengan akhlak, budi pekerti, perilaku, tabiat, watak, kepribadian, sifat, temperamen. Lickona (1991) (dalam Ismail, 2013) menegaskan bahwa secara garis besar terdapat dua nilai moral dasar karakter, yaitu: 1) respect, artinya menunjukkan penghargaan terhadap orang maupun hal lain, termasuk diri sendiri, orang lain, dan lingkungannya. 2) responsibility (tanggung jawab), yaitu memerhatikan pihak lain, dan bersedia secara aktif memenuhi kebutuhan.

\section{2) Konsep Pendidikan Karakter}

Megawangi (2004) menjelaskan pendidikan karakter sebagai usaha mendidik anak-anak agar dapat memutuskan dengan bijak dan mempraktikkannya dalam kehidupan sehari-hari, sehingga dapat berkontribusi positif kepada lingkungannya. Supriyoko (2011:29-40) menyatakan pendidikan karakter dapat 
dimaknai sebagai suatu proses internalisasi sifat-sifat utama yang menjadi ciri khusus dalam suatu masyarakat ke dalam diri siswa sehingga dapat tumbuh dan berkembang menjadi manusia dewasa, sesuai dengan nilai-nilai budaya masyarakat. Mulyasa (2011: 16-16) menyebutkan sembilan karakter tujuan pendidikan, yaitu: 1) religius, 2) tanggung jawab, disiplin, dan mandiri, 3) jujur, 4) hormat dan santun, 5) kasih sayang, peduli, dan kerja sama, 6) percaya diri, kreatif, kerja keras, dan pantang menyerah, 7) keadilan dan kepemimpinan, 8) baik dan rendah hati, serta 9) toleransi, cinta damai, dan persatuan.

3) Model Pembelajaran yang dikembangkan

Joyce dan Weil (2000: 39-47) mengetengahkan empat kelompok model pembelajaran, yaitu: 1) Cooperative learning models; 2) Information-processing models; 3) Personal models; 4) Behavioral systems models. Pengembangan model pembelajaran membaca mengacu pada model pembelajaran Borg and Gall (1983:775), yaitu: 1) Research and collecting (tahap studi pendahuluan), mencakup studi literatur yang berkaitan permasalahan yang dikaji yang melandasi produk model pembelajaran yang dikembangkan, observasi lapangan, dan persiapan untuk merumuskan kerangka kerja penelitian. 2) Planning (setelah studi pendahuluan dilakukan), merancang berbagai kegiatan dan proses dur peneitian serta pengembangan model pembelajaran membaca. 3) Develop preliminary form of produc (tahap ini bertujuan mengembangkan bentuk awal model pembelajaran yang akan diujicobakan dari produk yang akan dihasilkan). 4) Preliminary field testing (dilakukan ujicoba awal dalam skala terbatas dengan melibatkan subjek sebanyak 612 subjek). 5) Main product revision (dilakukan perbaikan terhadap produk awal yang dihasilkan berdasarkan hasil ujicoba awal). 6) Main field testing (uji coba utama yang melibatkan seluruh siswa kelas II di setiap sekolah penelitian). 7) Operational product revision (dilakukan penyempurnaan terhadap hasil uji coba lebih luas, sehingga produk yang dikembangkan sudah merupakan desain model operasional yang siap divalidasi). 8) Operational field testing (uji validasi terhadap model yang telah dihasilkan). 9) Final product revision (dilakukan perbaikan akhir terhadap produk yang dikembangkan guna menghasilkan produk akhir). 10) Dissemination and implementation (menyebarluaskan produk yang dikembangkan).

\section{METODE PENELITIAN}

\section{a. Jenis Penelitian}

Mengacu pada tujuan penelitian, model pembelajaran membaca berbasis permainan bagi pembentukan karakter (PMBP-PK) siswa kelas II Sekolah Dasar. Penelitian ini termasuk penelitian pengembangan (Research \& Development). Penelitian ini berpijak kepada model pengembangan Borg and Gall (1983) yang telah disederhanakan oleh Sukmadinata (2005), berikut ini. 


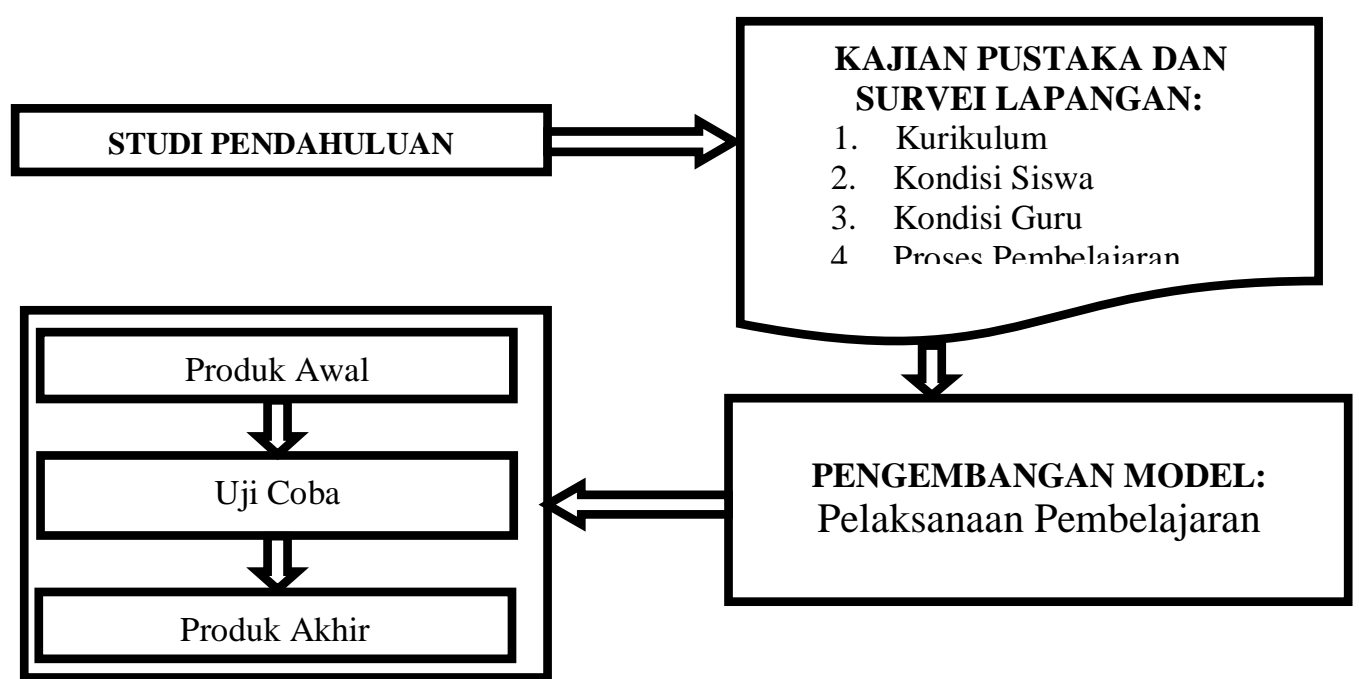

Gambar 3.1. Tahap Pengembangan Model (Borg \& Gall, 1983 dalam Sukmadinata, 2005)

\section{b. Variabel Penelitian}

Variabel penelitian: 1) nilai karakter terintegrasikan dalam pembelajaran membaca; 2) konstruksi model pembelajaran membaca berbasis permainan; 3) domain kognitif, afektif, dan psikomotor terintegrasi selama pembelajaran; dan 4) kualitas pembelajaran (valid, efektif, dan praktis) melalui implementasi pembelajaran.

\section{c. Definisi Operasional Variabel}

Definisi operasional variabel, yaitu: 1) Pembelajaran membaca berbasis permainan adalah bentuk permainan yang sesuai tingkat perkembangan siswa. 2) Model pembelajaran adalah kerangka konseptual yang sistematik dalam pengalaman belajar untuk mencapai tujuan pembelajaran. 3) Pengembangan perencanaan (Silabus, RPP, Bahan Ajar, LKS, dan Penilaian) yang valid, efektif, dan praktis; 4) Keterlaksanaan pembelajaran adalah melakukan pembelajaran di kelas yang berkualitas dengan menerapkan model PMBP-PK. 5) Pembentukan karakter adalah pengenalan nilai-nilai karakter melalui kegiatan membaca; 6) Model pembelajaran membaca berbasis permainan bagi pembentukan karakter (PMBP-PK) siswa kelas II Sekolah Dasar adalah langkah-langkah menyusun kerangka sistem pembelajaran membaca yang dikemas melalui permainan. 7) Nilai karakter adalah; cinta kepada Allah (religius), tanggung jawab, jujur, santun, kerja sama, percaya diri, rendah hati, dan disiplin.

\section{d. Rancangan Pengembangan}

Penelitian

Metode ini merujuk kepada teori Borg \& Gall (1983: 775) yang disederhanakan menjadi empat tahap pengembangan, yaitu: 1) Tahap Studi Pendahuluan; dilakukan identifikasi kebutuhan, mempelajari teori-teori pendukung, identifikasi terhadap hasilhasil penelitian dan asurvei lapangan. 2) Desain Produk Awal; langkah awal 
dalam tahapan research \& development (R\&D) adalah membuat produk pembelajaran untuk diujicobakan oleh validator ahli dan validator praktisi berupa Silabus, RPP, Materi/Bahan ajar siswa, LKS, Buku Guru, Buku Siswa, Keterlaksanaan Pembelajaran, dan Penilaian (proses dan hasil belajar). 3) Uji coba dan Revisi; dilakukan pada waktu uji coba, yaitu: a) penyamaan persepsi dengan guru mitra dan pengamat, b) uji coba lapangan penggunaan model perencanaan yang telah divalidasi. 4) Implementasi; pembelajaran membaca yang telah diujicobakan, diimplementasikan pada tiga SD yang dipilih untuk mengetahui hasil pengembangan model PMBP-PK yang memenuhi kategori valid, efektif, dan praktis bagi siswa kelas II Sekolah Dasar di Kota Makassar.

\section{e. Jenis Data dan Sumber Data}

Data yang dikumpulkan berupa data verbal lisan dan verbal tertulis. Data verbal lisan diperoleh dari saran atau kritikan tentang produk oleh ahli, praktisi, atau guru. Data verbal tertulis berupa wacana atau kutipan wacana untuk pembelajaran membaca yang bersumber dari bahan ajar lain yang berkarakter untuk kelas II pada Sekolah Dasar di Kota Makassar. Data hasil uji ahli dan praktisi yang diperoleh dalam penelitian ini merupakan data kuantitatif dan kualitatif. Data kualitatif berupa tanggapan, komentar, dan penilaian dari parsiapan selama proses pembelajaran, sedangkan data kuantitatif berupa skor penilaian uji kemampuan/pemahaman siswa membaca dari segi kelancaran membaca, pemahaman isi, lafal, dan intonasi.

\section{f. Instrumen Penelitian}

Peneliti berperan sebagai instrumen kunci pada pengumpulan data, analisis data, dan penafsiran data. Peneliti menggunakan instrumen bantu berupa format catatan lapangan, panduan penelaahan produk, dan angket, sedangkan pengumpulan data kuantitatif berupa skor kemampuan membaca yang berbasis permainan bagi pembentukan karakter (PMBP-PK) siswa kelas II sekolah dasar sejalan dengan pendapat Bogdan dan Biklen (1992 dalam Daeng, 2013).

\section{g. Teknik Pengumpulan Data}

Teknik pengumpulan data dalam penelitian pengembangan ini, peneliti menggunakan panduan untuk mengukur kevalidan, kefektifam, dan kepraktisan Model PMBP-PK. Instrumen yang dimaksud: 1) lembar validasi, 2) lembar observasi, 3) keterlaksanaan pembelajaran, 4) angket respons siswa dan guru, 5) lembar tes hasil belajar, dan 6) lembar pengamatan nilai karakter.

$$
\begin{array}{lll}
0-40=\text { Mulai Tampak }(\mathrm{MT}) \\
41-60= & \text { Mulai } & \text { Berkembang } \\
(\mathrm{MB}) & & \\
61-80= & \text { Sudah } & \text { Berkembang } \\
(\mathrm{SB}) & & \\
81-100= & \text { Menunjukkan } \\
\text { Kebiasaan (MK) } &
\end{array}
$$

\section{h. Teknik Analisis Data}

Hasil uji coba kevalidan, keefektifan, kepraktisan, dan kemenarikan model PMBP-PK yang dikembangkan dianalisis sesuai kritria. Analisis Kevalidan (valid-tidak valid), analaisis Keefektifan (data hasil belajar, respons siswa, guru, dan kemenarikan)

Kriteria tingkat keefektifan: 
$-81-100 \%=$ sangat efektif dan menarik (tidak perlu direvisi)

$-66-80 \%=$ efektif dan menarik (tidak perlu direvisi)

$-56-65 \%=$ kurang efektif dan kurang menarik (perlu direvisi)

$-0-55 \%=$ tidak efektif dan tidak menarik (perlu direvisi)

Analisis Kepraktisan (praktis-tidak praktis) Model PMBP-PK.

\section{HASIL PENELITIAN PENGEMBANGAN}

Ada tiga hal pokok yang dipaparkan, yaitu produk perencanaan pembelajaran, produk Keterlaksanaan pembelajaran, dan produk penilaian yang memenuhi kategori valid, praktis, dan efektif.

\section{a. Pengembangan Perencanaan Model PMBP-PK}

1) Pengembangan Silabus Model PMBP-PK

Hasil uji validator ahli tentang validasi isi silabus pengembangan model PMBP-PK bagi siswa kelas II SD di Kota Makassar dinyatakan valid. Keefektifan silabus berdasarkan hasil uji oleh validator ahli menunjukkan kesesuaian struktur dan kriteria pada kategori efektif yaitu mencapai 79,17\%. Hasil uji praktisi validasi isi silabus model PMBP-PK siswa kelas II Sekolah Dasar di Kota Makassar dinyatakan valid. Keefektifan silabus hasil uji validator praktisi tentang struktur dan kriteria pada kategori sangat efektif karena mencapai jumlah skor 127 atau mencapai $88,197 \%$. Keterlaksanaan uji coba lapangan silabus pada tiga sekolah dasar, yaitu: 1) SD Negeri Kompleks
Kapota Yudha, 2) SD Inpres Bertingkat Mamajang I, dan 3) SD Inpres Perumnas I di Kota Makassar. Kevalidan, keefektifan, dan kepraktisan silabus tampak pada keterlaksanaan pembelajaran sangat praktis mencapai skor 85 atau $88,54 \%$ (tinggi).

2) Pengembangan

Rencana

Keterlaksanaan Pembelajaran Model PMBP-PK

Hasil uji ahli validasi RPP dinyatakan valid karena mencapai skor 228 atau dikonversi mencapai 3,8 (valid). Keefektifan RPP pada kategori sangat efektif yaitu mencapai 92,04\% . Kesesuaian struktur dan kriteria mencapai skor 162 atau dikonversi menjadi 3,68 (sangat efektis). Hasil uji validator praktisi uji validasi $R P P$ pengembangan model PMBP-PK siswa kelas II Sekolah Dasar di Kota Makassar tergolong valid. Keefektifan RPP pada kategori sangat efektif $(94,32 \%)$. Hasil uji lapangan RPP tampak ketika pelakasanaan di kelas oleh validator ahli dan validator praktisi menunjukkan keterlaksanaan pada kategori sangat praktis, yaitu mencapai $91,66 \%$.

3) Pengembangan Materi/Bahan Ajar Hasil uji ahli kevalidan materi/bahan ajar model PMBP-PK siswa kelas II Sekolah Dasar di Kota Makassar dinyatakan valid. Keefektifan materi/bahan ajar tersebut pada kategori sangat efektif $(94,5 \%)$. Tingkat keefektifan mencapai 106 dikonversi mencapai 3,78 sangat efektif atau mencapai 94,64\%. Hasil uji praktisi kevalidan materi/bahan ajar dinyatakan valid karena mencapai skor 155 atau dikonversi mencapai 3,97. Keefektifan 
materi/bahan ajar membaca, hasil uji coba praktisi kategori sangat efektif (90,63\%). Permainan kesatu dan permainan kedua masing-masing mencapai $90,63 \%$, permainan ketiga mencapai $93,75 \%$, dan permainan keempat mencapai 87,5\%. Materi/bahan ajar yang dikembangkan sangat efektif.

Hasil uji lapangan materi/bahan ajar tema "kesehatan" pada permainan "Bisik Berantai" setiap sekolah, berada pada kategori sangan tinggi $(80,56 \%)$. Tema "Peristiwa" pada permainan "Baca Lakukan" pada kategori sangat tinggi $(82,06 \%)$. Tema "kegiatan seharihari" pada permainan "Meloncat Bulatan Kata" berada pada kategori sangat tinggi (83,09\%). Tema "Lingkungan" pada permainan "Kata dari Wacana" pada kategori sangat tinggi $(80,24 \%)$. Jadi hasil uji lapangan materi ajar dinyatakan praktis dari keempat permainan sesuai dengan tema, yaitu mencapai rerata skor 81,49 (tinggi).

\section{4) Pengembangan Lembar Kerja Siswa (LKS)}

Hasil uji kevalidan LKS oleh kelompok ahli pembelajaran membaca berbasis permainan bagi siswa (PMBPPK) kelas II Sekolah Dasar dinyatakan valid. Keefektifan pengembangan LKS berada pada kategori efektif karena mencapai 126 atau jika dikonversi menjadi 3,5 (sangat efektif) atau mencapai $87,5 \%$. Hasil uji kevalidan LKS oleh praktisi (tiga orang kepala sekolah) tentang model PMBP-PK bagi siswa kelas II Sekolah Dasar dinyatakan valid. Tingkat keefektifan pada kategori sangat efektif yaitu 93,06\%. Kesesuaian struktur dan kriteria mencapai 134 atau jika dikonversi menjadi 3,72 (sangat efektif) atau mencapai 93,06\%. Keterlaksanaan uji coba lapangan pada SD Negeri Kompleks Kapota Yudha sebanyak 35 orang, SD Inpres Bertingkat Mamajang I sebanyak 34 orang, dan SD Inpres Perumnas I sebanyak 32 orang di Kota Makassar.

\section{b. Keterlaksanaan Pembelajaran Model PMBP-PK}

1) Analisis Keterlaksanaan Pembelajaran Model PMBP-PK

Ada empat bentuk permainan, yaitu: "bisik berantai" tema kesehatan, "baca lakukan" tema peristiwa, "meloncat bulatan kata" tema kegiatan sehari-hari, dan "kata dari wacana" tema lingkungan. Dilaksanan pada tiga SD dengan uraian berikut: 1) Keterlaksanaan Model PMBP-PK pada permainan "Bisik Berantai" mencapai rerata nilai 4,52 (sangat efektif). SD-1 mencapai rerata skor 4,5 (sangat efektif), SD-2 mencapai rerata skor 4,57 (sangat efektif), dan SD-3 mencapai rerata skor 4.5 (sangat efektif). 2) Keterlaksanaan permainan "Baca lakukan" yang diajarkan pada tiga sekolah mencapai rerata nilai 4,55 (sangat efektif). SD-1 mencapai rerata skor 4,64 (sangat efektif), SD-2 mencapai rerata skor 4,5 (sangat efektif), dan SD-3 mencapai rerata skor 4.5 (sangat efektif). 3) Keterlaksanaan permainan "Meloncat Bulatan Kata" yang diajarkan pada tiga sekolah mencapai rerata nilai 4,51 (sangat efektif). SD-1 mencapai rerata skor 4,38 (efektif), SD-2 mencapai rerata skor 4,57 (sangat efektif), dan SD-3 mencapai rerata skor 4.57 (sangat efektif). 4) Keterlaksanaan permainan "Kata dari Wacana" mencapai rerata 
nilai 4,52 (sangat efektif). SD-1 mencapai rerata skor 4,64 (sangat efektif), SD-2 mencapai rerata skor 4,5 (sangat efektif), dan SD-3 mencapai rerata skor 4.43 (efektif).

Tabel Rerata Nilai Hasil Keterlaksanaan Pembelajaran setiap Permainan pada tiap Sekolah Model PMBP-PK di Kelas II Sekolah Dasar

\begin{tabular}{|l|l|l|l|l|l|l|}
\hline \multirow{2}{*}{ No. } & \multirow{2}{*}{ Bentuk Permainan } & \multicolumn{2}{l}{ Skor tiap Sekolah } & \multirow{2}{*}{ Skor Rerata } & \multirow{2}{*}{ Kategori } \\
\cline { 3 - 4 } & & SD-1 & SD-2 & SD-3 & & \\
\hline 1. & Bisik Berantai & 4,50 & 4,57 & 4,50 & $4,52=90,4 \%$ & S. Efektif \\
\hline 2. & Baca Lakukan & 4,64 & 4,50 & 4,50 & $4,55=91 \%$ & S. Efektif \\
\hline 3. & Meloncat Bulatan Kata & 4,38 & 4,57 & 4,57 & $4,51=90,2 \%$ & S. Efektif \\
\hline 4. & Kata dari Wacana & 4,64 & 4,50 & 4,43 & $4,52=90,4 \%$ & S. Efektif \\
\hline Jumlah & 18,16 & 18,14 & 18,00 & 18,10 & \\
\hline Rerata & $\mathbf{4 , 5 4}$ & $\mathbf{4 , 5 3}$ & $\mathbf{4 , 5}$ & $\mathbf{4 , 5 2}$ & S. Efektif \\
\hline Persentase Kepraktisan & $\mathbf{9 0 , 8 \%}$ & $\mathbf{9 0 , 6 \%}$ & $\mathbf{9 0 \%}$ & $\mathbf{9 0 , 4 \%}$ & S. Tinggi \\
\hline
\end{tabular}

2) Hasil Validasi Buku Guru Model PMBP-PK

Data penilaian validator ahli dan validator praktisi terhadap buku guru menunjukkan bahwa nilai rerata setiap aspek, yaitu: 1) format buku guru mencapai rerata skor 4,29 (valid); 2) ilustrasi buku guru mencapai rerata skor 3,73 (valid); 3) bahasa buku guru mencapai rerata skor 3,92 (valid); dan 4) isi buku guru mencapai rerata skor 4,3 (valid). Dengan demikian, dapat disimpulkan bahwa skor rerata aspek yang dinilai adalah 4,06 (valid). Hasil uji validator ahli dan validator praktisi keefektifan buku guru menunjukan hasil efektif.

3) Hasil Validasi Buku Siswa Model PMBP-PK

Data penilaian validator ahli dan validator praktisi terhadap buku siswa menunjukkan bahwa nilai skor rerata, yaitu 4,17 valid. Hasil uji validator ahli dan validator praktisi keefektifan buku siswa menunjukkan hasil setiap aspek yang dinilai, yaitu: 1) rerata skor keefektifan validator ahli mencapai 4,2; 2) rerata skor keefetifan validator praktisi mencapai 4,53. Dengan demikian, dapat disimpulkan bahwa total nilai rerata keefektifan buku siswa 4,36 atau mencapai tingkat persentasi $87,2 \%$ efektif.

4) Analisis Keterlaksanaan Nilai Karakter Siswa

Hasil nilai karakter siswa pada tiga sekolah yang disajikan dengan model PMBP-PK, menunjukkan nilai rerata karakter 3,39, jika dikonfirmasikan dengan persentase mencapai $84,83 \%$. Nilai karakter yang tampat dapat dilihat pada diagram berikut. 


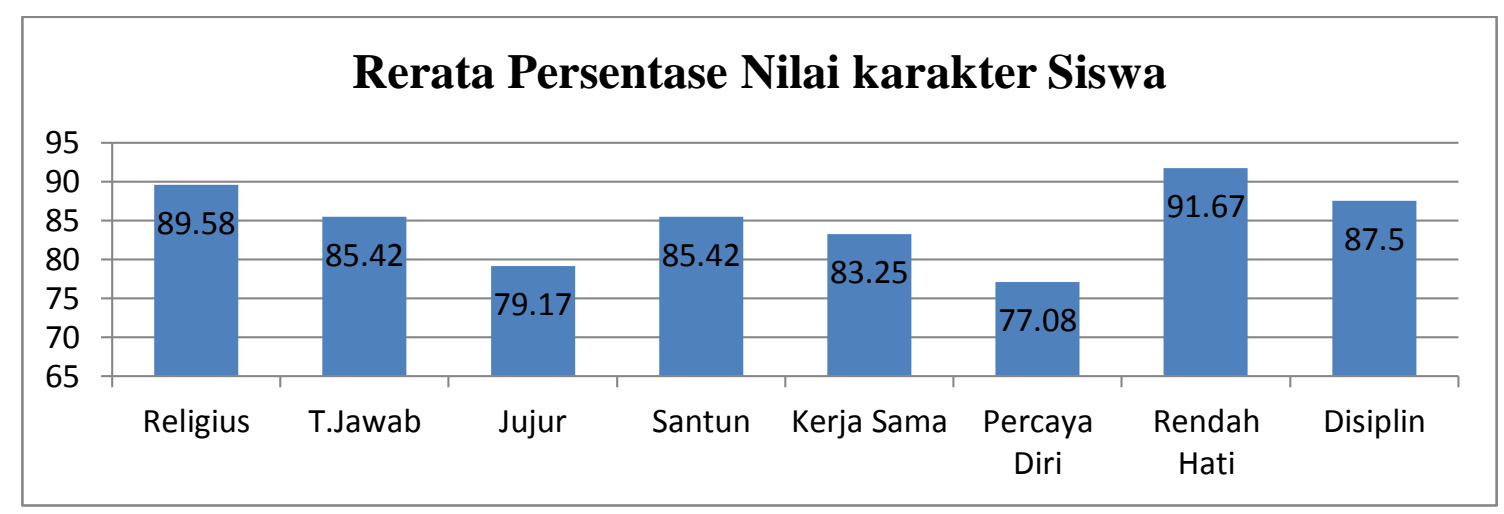

5) Analisis Respons dan Kemenarikan Siswa terhadap Model PMBP-PK

Respons dan kemenarikan siswa pada keterlaksanaan pembelajaran model PMBP-PK sesuai angket menunjukkan bahwa sebanyak 5\% siswa menyatakan sulit, $27,35 \%$ siswa menyatakan agak sulit, dan 67,65\% menyatakan tidak sulit mengikuti pembelajaran. Kegiatan pembelajaran berkaitan dengan model PMBP-PK terdapat $26,47 \%$ siswa menyatakan sukup sulit, terdapat $73,53 \%$ siswa menyatakan tidak sulit. Berkaitan dengan buku siswa, ada 70,59\% siswa menyatakan setuju, ada $29,41 \%$ siswa menyatakan sangat setuju, dan tidak ada $(0 \%)$ siswa menyatakan tidak setuju. Keterkaitan buku siswa dalam mengerjakan tugas-tugas pada LKS terdapat $58,82 \%$ siswa menyatakan setuju, terdapat $41,18 \%$ siswa sangat setuju, dan $0 \%$ siswa tidak setuju. Tentang tugas dalam LKS dapat diselesaikan sesuai dengan waktu yang disediakan sebanyak $52,94 \%$ siswa setuju, 47,06\% siswa sangat setuju, dan $0 \%$ siswa tidak setuju. Siswa yang merasakan ada kemajuan, termotivasi, dan memiliki nilai karakter setelah mengikuti pembelajaran model PMBPPK terdapat $91 \%$ siswa menyatakan ya dan 9\% siswa menyatakan tidak berminat.

Persentase kemenarikan siswa pada model PMBP-PK, menunjukkan: 1) aktivitas pembelajaran siswa yang menyatakan cukup senang $1,47 \%$, yang menyatakan senang $57,84 \%$, dan menyatakan sangat senang $40,69 \%$; 2) terkait dengan buku siswa $4,9 \%$ siswa menyatakat cukup senang, 44,12\% siswa menyatakan senang, dan $50,98 \%$ siswa menyatakan sangat senang; dan 3) terkait dengan lembar kerja siswa (LKS) $91,1 \%$ siswa menyatakan setuju dan $8,9 \%$ siswa menyatakan tidak setuju. Hal ini aktivitas pembelajaran, penggunaan buku siswa dan LKS termotivasi dan memiliki kemenarikan bagi siswa.

6) Analisis Respons Guru terhadap Penerapan Model PMBP-PK

Respons guru terhadap model PMBP-PK siswa kelas II Sekolah Dasar menunjukkan bahwa: 1) seluruh komponen kegiatan pembelajaran membantu dalam penguasaan dan pemahaman isi teks serta penanaman nilai karakter; dan 2) respons guru terhadap komponen perangkat pembelajaran sangat membantu dalam proses pembelajaran, penyususnan 
perangkat, dan penanaman nilai karakter.

Keterlaksanaan pembelajaran model PMBP-PK pada siswa kelas II Sekolah Dasar menunjukkan syarat minimal 75\% oleh Borich 1994 (dalam Ismail, 2013:182). Posisi nilai karakter siswa minimal mencapa Menjadi Kebiasaan (MK) yaitu 84,25\%. Hasil belajar siswa menunjukkan bahwa ketuntasan minimal secara klasikal yaitu $85,7 \%$. Respons positif guru sangat membantu dalam proses pembelajaran.

\section{c. Pengembangan Penilaian Model PMBP-PK}

1) Penilaian Proses Pembalajaran Model PMBP-PK

Pengembangan produk penilaian proses model PMBP-PK dilakukan saat pembelajaran atau unjuk kerja. Hasil uji validator bertujuan untuk memeroleh informasi kevalidan dan keefektifan penilaian proses melalui lembar pedoman penilaian model PMBP-PK. Hasil uji validator ahli tentang kevalidan penilaian proses pada kategori valid mencapai 4,57. Keefektifan model PMBP-PK sesuai teori membaca dan pedoman penilaian akhir berbaisis permainan dinyatakan efektif. Persentase permainan ke-1 mencapai 83,33\% (efektif), permainan ke-2 mencapai $75 \%$ (efektif), permainan ke-3 mencapai 83,33\% (efektif), dan permainan ke-4 mencapai $66,67 \%$ (kurang efektif).

Hasil uji validator praktisi tentang kevalidan penilaian proses valid, yaitu 4,67. Keefektifan model penilaian akhir menunjukkan bahwa uji keefektifan penilaian hasil akhir pembelajaran pada kategori sangat efektif $(97,92 \%)$. Persentase setiap permainan, yaitu: permaian ke-1 mencapai 93,75\% (sangat efektif), permainan ke-2, ke-3, dan ke-4 masingmasing mencapai $100 \%$ (sangat efektif).

Hasil uji lapangan penilaian proses oleh guru setiap sekolah siswa kelas II Sekolah Dasar dengan jumlah masingmasing siswa bervariasi, yaitu SD. $1=35$ orang, SD.2=34 orang, dan SD.3=32 orang. Hasil penilaian proses umumnya siswa mengikuti pembelajaran dengan baik berperilaku positif atau kategori baik. Aktif memerhatikan penjelasan guru, bermainan sesuai petunjuk, membaca buku materi buku, mengerjakan dan menyesaikan soal-soal pada LKS, menyampaikan pendapat kepada guru, menanyakan yang tidak dimengerti kepada guru, bertanya kepada teman, menarik kesimpulan pembelajaran, menunjukkan perilaku positif.

2) Penilaian Hasil Pembalajaran Model PMBP-PK

Hasil uji validator ahli kevalidan penilaian hasil belajar diperoleh berdasarkan indikator terhadap aspek yang dinilai pada model PMBP-PK siswa kelas II Sekolah Dasar dinyatakan valid mencapai 127 dengan nilai rerata 4,23 . Hasil uji keefektifan oleh validator ahli tentang penilaian hasil belajar membaca efektif dengan tingkat keefektifan pada kategori sangat efektif, yaitu $85,42 \%$.

Hasil uji validator praktisi tentang kevalidan penilaian hasil belajar diperoleh berdasarkan indikator terhadap aspek dengan menggunakan format validasi sebagai rambu-rambu analisis penilaian hasil belajar model 
PMBP-PK siswa kelas II Sekolah Dasar dinyatakan valid mencapai jumlah 137 dengan nilai rerata 4,57 kategori sangat valid. Hasil uji keefektifan oleh validator praktisi tentang penilaian hasil belajar dan pedoman penilaian akhir mencapai kategori sangat efektif, yaitu $97,92 \%$.

Hasil uji lapangan terhadap penilaian model PMBP-PK bagi siswa kelas II permainan kesatu "bisik berantai” kategori baik (78,89), permainan kedua "baca lakukan", kategori sangat baik $(80,55)$, permainan "meloncat bulatan kata", kategori baik $(79,16)$, permainan "kata dari wacana", kategori baik $(77,92)$.

Rerata nilai tes hasil belajar siswa kelas II tentang pemahaman dan penguasaan isi wacana/teks sesuai dengan rekapitulasinya dapat dilihat pada Tabel berikut ini.

Tabel Rekapitulasi Nilai Individual setiap Sekolah

\begin{tabular}{|l|l|l|l|l|l|}
\hline \multirow{2}{*}{ No. } & \multirow{2}{*}{ Nama Sekolah } & \multicolumn{2}{|l|}{ Rerata Hasil Tes Uji Lapangan } & \multirow{2}{*}{ Keterangan } \\
\cline { 3 - 5 } & & Pretest & Posttest & $\begin{array}{l}\text { Ketuntasan } \\
\text { Klasikal (\%) }\end{array}$ & \\
\hline 1. & SD Negeri Kapota Yudha & 49,43 & 78,86 & 85,7 & \\
\hline 2. & SD Inpres Mamajang I & 54,41 & 76,62 & 82,35 & \\
\hline 3. & SD Inpres Perumnas I & 45,47 & 73,44 & 78,13 & \\
\hline \multicolumn{2}{|l|}{ Rerata } & $\mathbf{4 9 , 7 7}$ & $\mathbf{7 6 , 3 1}$ & $\mathbf{8 2 , 0 6}$ & \\
\hline
\end{tabular}

Berdasarkan Tabel di atas, disimpulkan bahwa rerata perolehan nilai tes tertulis (pretes dan postes), yaitu: 1) SD Negeri Kapota Yudha memeroleh nilai pretes 49,43 dan nilai postes 78,86 dengan ketuntasan klasikal $85,7 \%$, 2) SD Inpres Mamajang I memeroleh nilai pretes 54,41 dan postes 76,62 dengan ketuntasa klasikal 82,35, dan 3) SD Inpres Perumnas I memeroleh nilian pretes 45,47 dan nilai postes 73,44 dengan ketuntasan klasikal $78,13 \%$.

\section{PEMBAHASAN PENGEMBANGAN}

HASIL

Karakteristik model PMBP-PK, hasil uji coba model PMBP-PK, yaitu berupa bentuk permainan, nilai karakter, dan hasil belajar membaca siswa kelas II Sekolah Dasar, yaitu aspek proses dan aspek kualitas.

\section{a. Karakteristik Model PMBP-PK Siswa Kelas II SD pada Aspek Proses}

Karakteristik model PMBP-PK siswa kelas II Sekolah Dasar pada aspek proses pembelajaran membaca berbasis permainan beranjak dari permasalahan kurang berminatnya siswa membaca. Sebagaimana yang diungkapkan Taufik Ismail (1998) bangsa kita telah menjadi bangsa yang rabun membaca buku dan merosot kemampuannya dalam mengemukakan pikiran dalam bentuk karangan.

Pelaksanaan pembelajaran membaca melalui permainan bisik berantai sesuai dengan petunjuk yang tertera dalam buku siswa dan Lembar Kerja Siswa (LKS 1), yaitu menyampaikan pesan pendek secara berantai. Permainan ini diawali dengan membaca teks. Hasil kerja, siswa diminta membaca teks dengan lafal dan intonasi yang tepat, menyebutkan isi 
teks dengan kalimat yang santun menunjukkan hasil 80,56\% kategori tinggi.

Permainan baca lakukan yang dilaksanakan sesuai dengan petunjuk yang tertera dalam buku siswa dan Lembar Kerja Siswa (LKS 2). Permainan ini dilakukan secara berpasangan. Seorang siswa membaca dengan jelas dan intonasi yang tepat kalimat yang ditulis oleh Ibu Guru dan pasangannya harus melakukan apa yang dibacakan itu. Permainan ini diawali dengan membaca teks. Hasil yang diperoleh menunjukkan hasil 82,06\% kategori tinggi.

Permainan meloncat bulatan kata yang dilaksanakan sesuai dengan petunjuk yang tertera dalam buku siswa dan Lembar Kerja Siswa (LKS 3). Permainan ini untuk melatih kemampuan membaca permulaan. Permainan ini dilakukan secara berpasangan. Permainan ini diawali dengan membaca teks. Hasil yang diperoleh pada permainan ini menunjukkan hasil $83,09 \%$ kategori tinggi.

Permainan kata dari wacana yang dilaksanakan sesuai dengan petunjuk yang tertera dalam buku siswa dan Lembar Kerja Siswa (LKS 4). Permainan ini untuk melatih keterampilan membaca dan kosakata. Permainan ini dilakukan secara berkelompok. Permainan ini diawali dengan membaca teks puisi. Hasil dari permainan ini menunjukkan hasil $80,24 \%$ kategori tinggi.

\section{b. Karakteristik Model PMBP-PK Siswa Kelas II SD pada Aspek Kualitas}

Karakteristik yang kedua pada model PMBP-PK siswa kelas II Sekolah Dasar, yaitu: aspek kualitas. Inti masalah penelitian pada aspek kualitas ini, yaitu: "Bagaimanakah Perencanaan, Keterlaksanaan, dan Penilaian proses dan hasil pembelajaran membaca yang memenuhi kategori valid, efektif, dan praktis bagi pembentukan karakter siswa kelas II Sekolah Dasar?"

\section{c. Kevalidan Perencanaan Model PMBP-PK Siswa Kelas II SD}

Hasil uji validasi oleh validator ahli dan validator praktisi untuk perencanaan pembelajaran tentang isi silabus diperoleh skor 3,53 dan skor 4,05 dinyatakan memenuhi kriteria valid. RPP diperoleh skor 3,8 memenuhi kriteria valid. Materi/bahan ajar diperoleh skor 3,62 dan skor 3,97 dinyatakan memenuhi kriteria valid. LKS diperoleh skor 4,0 dan skor 4,37 dinyatakan memenuhi kriteria valid. Hasil validasi ahli dan praktisi tentang penilaian yang meliputi penilaian proses dan hasil diperoleh skor 4,57 dan skor 4,67 dinyatakan memenuhi kriteria valid. Validasi ahli dan praktisi tentang penilaian hasil belajar diperoleh skor 4,23 dan skor 4,57 dinyatakan memenuhi kriteria valid. Sementara hasil validasi buku guru oleh validator ahli dan praktisi diperoleh skor rata 4,06 dan validasi buku siswa diperoleh skor rata-rata 4,17 dinyatakan memenuhi kriteria valid.

\section{d. Keefektifan Model PMBP-PK Siswa Kelas II SD \\ Hasil uji kefektifan oleh validator} ahli dan validator praktisi untuk perencanaan pembelajaran tentang isi 
silabus diperoleh skor $3,17(79,17 \%)$ dan skor 3,53 (88,19\%) dinyatakan memenuhi kriteria efektif. RPP diperoleh skor 3,68 $(92,04 \%)$ dan skor 3,77 (94,32\%) dinyatakan memenuhi kriteria efektif. Materi/bahan ajar diperoleh skor $3,79(94,64 \%)$ dan skor $3,62(90,63 \%)$ dinyatakan memenuhi kriteria efektif. LKS diperoleh skor 3,5 $(87,5 \%)$ dan skor 3,72 (93,06\%) dinyatakan memenuhi kriteria efektif sesuai dengan yang ditetapkan.

Hasil uji keefektifan validator ahli dan praktisi tentang penilaian yang meliputi penilaian proses dan hasil diperoleh skor 3,08 $(77,8 \%)$ dan skor 3,92 (97,92\%) dinyatakan memenuhi kriteria efektif. Keefektifan validator ahli dan praktisi tentang penilaian proses dan hasil belajar diperoleh skor $3,42(85,42 \%)$ dan skor 3,92 $(97,92 \%)$ dinyatakan memenuhi kriteria efektif. Sementara hasil uji validator keefektifan buku guru diperoleh skor rata-rata 4,21 $(84,3 \%)$ dan buku siswa diperoleh skor rata-rata $4,36 \quad(87,2 \%)$ dinyatakan memenuhi kriteria efektif yaitu sangat efektif karena didukung oleh perangkat pembelajaran.

\section{e. Kepraktisan Model PMBP-PK Siswa Kelas II SD}

Hasil uji validator kepraktisan perencanaan pembelajaran uji lapangan pada masing-masing sekolah tentang isi silabus diperoleh skor 88,54\% dinyatakan praktis atau tinggi. RPP diperoleh skor $91,66 \%$ sangat tinggi (sangat praktis). Materi/bahan ajar dengan tema kesehatan dikemas melalui permainan bisik berantai diperoleh nilai $80,56 \%$ tinggi (praktis), tema peristiwa melalui permainan baca lakukan $82,06 \%$ tinggi (praktis), tema kegiatan sehari-hari melalui permainan meloncat bulatan kata 83,09\% sangat tinggi (sangat praktis), dan materi tema lingkungan melalui permainan kata dari wacana diperoleh nilai $80,24 \%$ sangat tinggi (sangat praktis). LKS diperoleh nilai 95,83\% sangat tinggi (sangat praktis) memenuhi kriteria. Penilaian diperoleh rata-rata nilai dari empat bentuk permainan yaitu 77,26 (tinggi). Hasil uji pretes mencapai rata-rata nilai 49,77 meningkat pada uji postes menjadi 76,31 dan ketuntasan klasikal mencapai $78,73 \%$ mencapai kategori tinggi. Buku guru diperoleh skor ratarata $4,27(85,4 \%)$ dan buku siswa diperoleh skor rata-rata 4,48 $(89,6 \%)$ dinyatakan praktis.

\section{f. Hasil Respons Guru, Siswa, dan Kemenarikan pada Model PMBP-PK}

Pembelajaran dengan model PMBP-PK dan perangkat pembelajaran, buku guru, buku siswa direspons positif dan menarik bagi siswa. Pembelajaran yang dikemas melalui permainan, direspons siswa di atas 50\% setuju dan $91 \%$ siswa termotivasi mengikuti pembelajaran.

Kemenarikan siswa terhadap pembelajaran model PMBP-PK menyatakan senang di atas $50 \%$ siswa sangat senang, $91,18 \%$ siswa menyatakan berminat. Sementara respons guru penerapan model PMBPPK dengan perangkat pembelajaran sesuai komponen layak digunakan.

Ketuntasan klasikal hasil belajar membaca, yaitu: 1) SD Negeri Kapota Yudha mencapai 85,7\% dengan nilai rata-rata kelas 78,86 tinggi dari 35 orang siswa terdapat 5 orang siswa yang tidak tuntas belajarnya; 2) SD Inpres 
Mamajang I mencapai $82 \%$ dengan nilai rata-rata kelas 76,62 tinggi dari 34 orang siswa terdapat 6 orang siswa yang belum tuntas belajarnya; dan 3) SD Inpres Perumnas I mencapai 78,13\% dengan nilai rata-rata kelas 73,44 kategori tinggi dengan KKM yaitu 70 .

Model PMBP-PK efektif dan dapat meningkatkan hasil belajar bahasa Indonesia aspek membaca siswa kelas II Sekolah Dasar yang dikemas merlalui permainan sesuai dengan tingkat perkembangan siswa.

\section{g. Temuan Penelitian}

\section{Perencanaan Pembelajaran Model PMBP-PK}

Informasi tentang: 1) kevalidan, keefektifan, dan kepraktisan isi silabus dinyatakan memenuhi kriteria untuk diaplikasikan; 2) kevalidan, keefektifan, dan kepraktisan komponen RPP yang telah dilaksanakan dinyatakan memenuhi kriteria; 3) evalidan, keefektifan, dan kepraktisan materi/bahan ajar; 4) kevalidan, keefektifan, dan kepraktisan tentang komponen LKS memenuhi kriteria yang telah ditetapkan dan dapat menampakkan nilai karakter yang dapat terbentuk dari siswa.

\section{Keterlaksanaan Pembelajaran Model PMBP-PK}

Pembelajaran dengan model PMBPPK dengan perencanaan yang telah disusun memenuhi kriteria kevalidan, keefektifan, dan kepraktisan. Keterlaksanaan pembelajaran model PMBP-PK pada tiga SD di Kota Makassar, yaitu: 1) SD Negeri Kompleks Kapota Yudha dengan jumlah siswa 35 orang, 2) SD Inpres
Mamajang I dengan jumlah siswa 34 orang, 3) SD Inpres Perumnas I dengan jumlah siswa 32 orang.

Jenis permainan yang dituangkan dalam perangkat pembelajaran, yaitu: 1) Bisik Berantai dengan tema wacana 'kesehatan', 2) Baca Lakukan dengan tema wacana 'peristiwa', 3) Meloncat Bulatan Kata dengan tema wacana 'kegiatan sehari-hari', dan 4) Kata dari Wacana dengan tema wacana 'lingkungan'. Keempat bentuk permainan dalam Keterlaksanaan pembelajaran dinyatakan praktis mencapai skor $90,04 \%$ pada kategori sangat tinggi.

Informasi kevalidan buku guru oleh validator ahli dan praktisi diperoleh rerata skor 4,06 memenuhi kriteria valid. Keefektifan buku guru model PMBP-PK diperoleh rerata skor 4,21 memenuhi kriteria efektif. Kepraktisan buku guru setelah uji lapangan dinyatakan praktis sesuai dengan kriteria yang telah ditetapkan. Informasi kevalidan buku siswa oleh validator ahli dan praktisi diperoleh rerata skor 4,17 memenuhi kriteria valid. Keefektifan buku siswa model PMBP-PK diperoleh rerata skor 4,36 memenuhi kriteria efektif. Sedangkan kepraktisan buku siswa setelah uji lapangan dinyatakan praktis sesuai dengan kriteria yang telah ditetapkan.

\section{Penilaian Pembelajaran}

Pengembangan penilaian model PMBP-PK, yaitu penilaian proses dan penilaian hasil. Kevalidan dan keefektifan penilaian yang ditunjang oleh teori dalam menyusun penilaian, baik penilaian (proses dan hasil belajar). Ada empat hal pokok yang menjadi fokus penilaian, yaitu: 1) memilih jenis 
penilaian yang tepat sesuai dengan permainan pembelajaran yang dilakukan, 2) memerhatikan bentuk, bahasa, dan struktur/komponen, 3) menyusun kisi-kisi penilaian sesuai dengan materi/bahan ajar, dan 4) memahami karakter apa yang diharapkan terbentuk dari siswa (khusus pada penilaian proses).

Model PMBP-PK dapat dimanfaatkan dalam pembelajaran, karena: 1) memudahkan guru untuk meningkatkan kinerja dalam menyusun perencanaan, melaksanakan pembelajaran, dan menilai pembelajaran (proses atau hasil), 2) membantu siswa memudahkan dan mengarahkan kegiatan pembelajaran membaca, 3) bermanfaat sebagai referensi untuk pembelajaran membaca yang kreatif, 4) bermanfaat meningkatkan motivasi dan minat membaca siswa, 5) dapat dijadikan masukan kepada penentu kebijakan pendidikan. Berikut temuan penelitian:

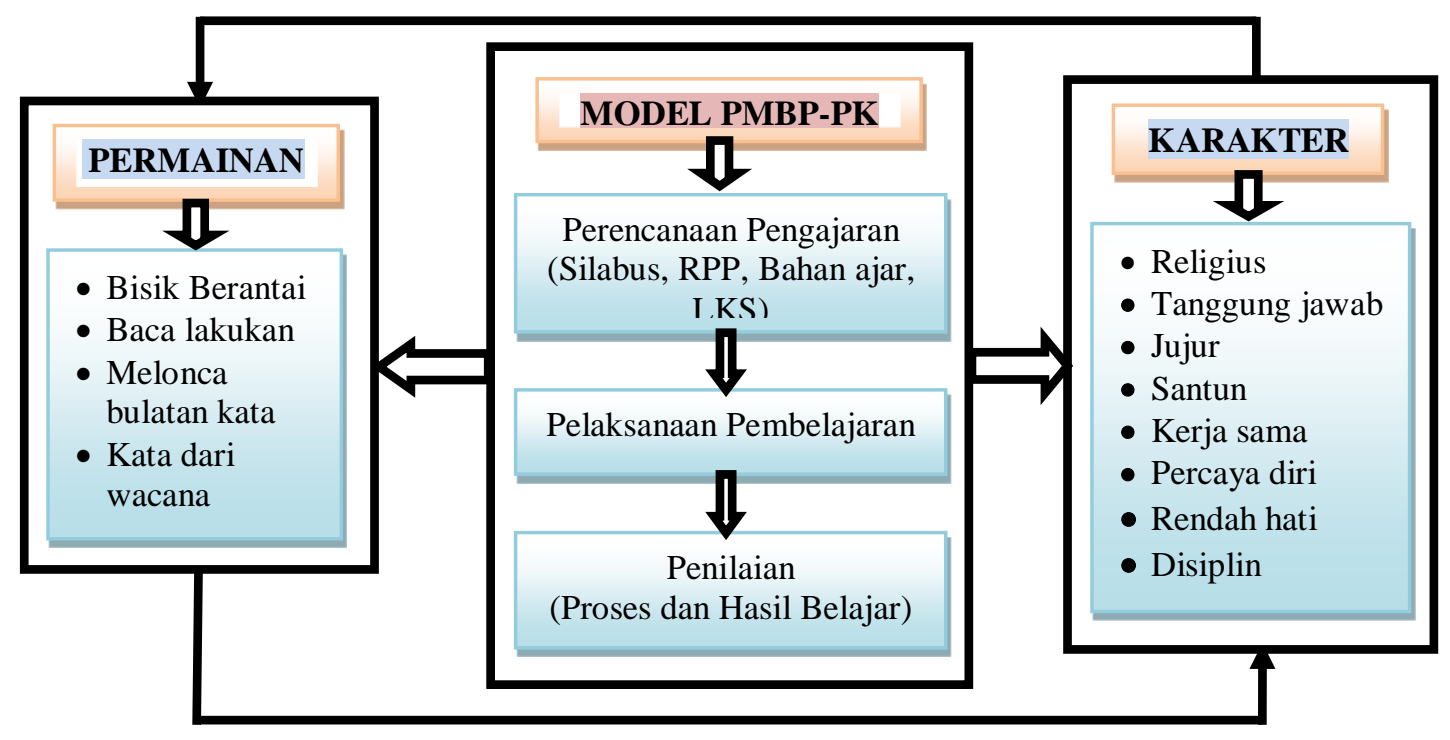

Gambar Temuan pada Model PMBP-PK

2. Implikasi Hasil Pengembangan Model PMBP-PK

Model PMBP-PK ini memuat sejumlah komponen yang terkait pengembangan produk berupa: 1) Perencanaan (Silabus, RPP, Materi ajar, Keterlaksanaan, dan penilaian) pembelajaran. 2) Pelaksanaan pembelajaran model PMBP-PK lebih hidup, kondusif, dan lebih menantang. 3) Aktivitas pembelajaran membaca melalui permainan, yaitu: 1) materi kesatu tema "Kesehatan" yang dikemas permainan "Bisik Berantai". 2) Materi kedua tema "Peristiwa" yang dikemas permainan "Baca lakukan". 3) Materi ketiga teman "Kegiatan sehari-hari" yang dikemas permainan "Meloncat 
bulatan kata". 4) Materi keempat dengan tema "Lingkungan" yang dikemas permainan "Kata dari Wacana".

Keterlaksanaan model PMBP-PK ini dilengkapi dengan media kartu kata, kartu kalimat, dan media langsung pembacaan puisi. Hal ini bertujuan untuk mempercepat imajinasi siswa dalam proses mewujudkan pembelajaran PAIKEM. Skenario penataan kelas dengan model kooperatif. Siswa dibentuk dalam kelompok yang heterogen yang anggotanya terdiri atas 4-6 orang setiap kelompok. Skenario permainan "Baca Lakukan" ini bertujuan melatih kemampuan siswa membaca dan menyimak. Kegiatan yang dilakukan dalam permainan ini, yaitu diawali dengan membaca teks pendek. Skenario permainan "Meloncat Bulatan Kata", yaitu kegiatan ini diawali dengan membaca teks singkat yang bertema kegiatan sehari-hari. Permainan ini bertujuan untuk melatih kemampuan membaca permulaan. Kegiatan ini diawali dengan membaca teks sederhana. Skenario permainan "Kata dari Wacana" diawali dengan pembacaan teks puisi yang bertema lingkungan dengan intonasi dan lafal yang tepat. Kegiatan yang dilakukan siswa, menuliskan kata yang menarik, untuk mencarikan padanannya.

Model PMBP-PK terhadap penilaian dalam penelitian ini adalah penilaian proses dan hasil. Penilaian proses dilaksanakan selama pembelajaran. Penilaian hasil dilaksanakan setelah pembelajaran berakhir. Model penilaian pembelajaran ini dilengkapi dengan panduan observasi, pedoman penilaian. Panduan observasi terdiri atas dua, yaitu panduan aktivitas mengajar dan panduan aktivitas siswa dalam pembelajaran membaca. Pedoman akhir dalam pembelajaran ini digunakan untuk menilai pekerjaan siswa secara utuh. Implikasi penilaian dapat memotivasi siswa belajar dan dapat meningkatkan kinerja guru untuk mengetahui kekurangan dan kelebihan pembelajaran yang dilakukan.

Produk penelitian pengembangan Model PMBP-PK ini disarankan dapat didesiminasikan secara luas, yaitu: melalui seminar atau lokakarya, melalui pusat-pusat kegiatan belajar (PKG), melalui pengiriman jurnal atau presentasi ilmiah, produk model PMBPPK melalui penerbitan buku model.

\section{KESIMPULAN DAN SARAN}

\section{a. Kesimpulan}

Pengembangan Silabus model PMBP-PK berdasarkan hasil uji validator (ahli dan praktisi dan hasil uji lapangan) dinyatakan valid, efektif, dan praktis dengan skor rata-rata tingkat kevalidan mencapai 3,79, tingkat keefektifan mencapai $83,68 \%$, dan tingkat kepraktisan mencapai $88,54 \%$ (sesuai dengan kriteria yang ditetapkan mencapai nilai tinggi).

Pengembangan RPP model PMBPPK berdasarkan hasil uji validator dan hasil uji lapangan dinyatakan valid, efektif, dan praktis digunakan dengan skor rata-rata tingkat kevalidan mencapai 3,98, tingkat keefektifan mencapai $93,18 \%$, dan tingkat kepraktisan mencapai 91,66\% (sesuai dengan kriteria yang ditetapkan nilai tinggi). 
Pengembangan Materi/Bahan Ajar model PMBP-PK berdasarkan hasil uji validator dan hasil uji lapangan dinyatakan dinyatakan valid, efektif, dan praktis dengan skor rata-rata tingkat kevalidan mencapai 3,79, tingkat keefektifan mencapai 92,63\%, dan tingkat kepraktisan dari keempat permainan disesuaikan dengan tema mencapai skor rerata 81,49 (kategori sangat tinggi).

Pengembangan LKS model PMBPPK berdasarkan hasil uji validator dan hasil uji lapangan dinyatakan valid, efektif, dan praktis dengan skor rerata tingkat kevalidan mencapai 4,18, tingkat keefektifan mencapai 90,28\%, dan tingkat kepraktisan mencapai 95,83\% (sesuai dengan kriteria yang ditetapkan, yaitu tinggi).

Pengembangan Keterlaksanaan pembelajaran Model PMBP-PK dinyatakan valid, efektif, dan praktis digunakan. Kevalidan Keterlaksanaan pembelajaran ditunjang perangkat perencanaan, buku guru, dan buku siswa. Efektif keterlaksanaan pembelajaran melalui permainan mencapai skor rerata $90,4 \%$, keefektifan buku guru mencapai $84,3 \%$, keefektifak buku siswa mencapai $87,2 \%$. Kepraktis karena model PMBP-PK setelah uji lapangan mencapai skor rerata $90,4 \%$, kepraktisan buku guru mencapai 85,4\% tinggi, dan kepraktisan buku siswa mencapai 89,6\% tinggi.

Pengembangan penilaian proses Model PMBP-PK bagi siswa kelas II SD dinyatakan valid, efektif, dan praktis dengan skor rerata tingkat kevalidan mencapai 4,62, rerata tingkat keefektifan mencapai 87,5\%, dan tingkat kepraktisan mencapai kategori baik dan direspons positif oleh siswa.
Berdasarkan uji validator dan uji lapangan penilaian hasil belajar dinyatakan valid, efektif, dan praktis. Tingkat kevalidan mencapai rerata skor 4,4, tingkat keefektifan mencapai $91,67 \%$, dan tingkat kepraktisan dari empat permainan sesuai dengan tema mencapai rerata 79,13 (kategori tingg). Rerata hasil belajar secara individual setiap sekolah, nilai pretest 49,77, posttest 76,31, dan ketuntasan klasikal $82,06 \%$.

Karakter yang terbentuk selama PBM berlangsung, yaitu: religius, jujur, tanggung jawab, santun, kerja sama, rendah hati, percaya diri, dan disiplin.

\section{b. Saran}

1) Model pembelajaran membaca berbasis permainan bagi pembentukan karakter (PMBP-PK) siswa kelas II Sekolah Dasar dapat diaplikasikan dengan berorientasikan pada proses kreatif dan aktivitas siswa.

2) Pengembangan model PMBP-PK yang telah diimplementasikan, maka disarankan kepada para guru sekolah dasar dapat menerapkan model ini dalam proses pembelajaran bahasa Indonesia pada aspek membaca.

3) Disarankan pula kepada pemerintah, Dinas Pendidikan untuk memfasilitasi guru menerapkan model PMBP-PK ini karena dapat meningkatkan hasil belajar siswa.

\section{DAFTAR PUSTAKA}

$\begin{array}{ccr}\text { Abbas, Abd Hamid. 1992. Pengaruh } \\ \text { Bentuk } & \text { Pertanyaan } & \text { Bacaan } \\ \text { Terhadap } & \text { Peningkatan Hasil }\end{array}$ 
Belajar Membaca Pemahaman Bahasa Inggris Siswa Sekolah Menengah Umum Tingkat Atas (SMA). Disertasi Program Pascasarjana Institut Keguruan dan Ilmu Pendidikan Malang.

Borg, Walter R \& Gall, Meredith D. 1983. Educational Research: An Introduction. London: Longman.

Brown, Douglas. 1987. Principles of Language Learning and Teaching. New Jersey: Prentice Hall.

Crawley, S.J. dan Mountain, L. 1995. Strategies for Guiding Content Reading. Boston. Allyn and Bacon.

Daeng, Kembong. 2013. Pengembangan Materi Pembelajaran Bahasa Makassar Siswa Kelas VII SMP/MTs di Sulawesi Selatan. Disertasi Program Pascasarjana Universitas Negeri Makassar.

Degeng, Nyoman SD. 2001. Pedoman Penyusunan Bahan Ajar (Menuju Pribadi Unggul). Malang: LPPP Universitas Negeri Malang.

Depdikbud. 1994. Kurikulum Pendidikan Dasar. Jakarta: Proyek Peningkatan Mutu SD, TK, dan SLB.

Djuanda, Dadan. 2006. Pembelajaran Bahasa Indonesia yang Komunikatif dan Menyenangkan. Jakarta: Depdiknas

Djumingin, Sulastriningsih. 2012. Pengembangan PMBP-PK dengan Model Sinestik di Universitas Negeri Makassar. Disertasi Program Pascasarjana Universitas Negeri Makassar.

Dworetzky, John. P. 1990. Introduction to Child Development. New York: West Publishing Company.
Hamid, Hamdani. 2012. Pengembangan Kurikulum Pendidikan. Bandung: Pustaka Setia.

Hanafie, St. Hawang. 1998. Baca Cepat dan Efektif. Alternative Tuntutan Alih Informasi dalam Meningkatkan Sumber Daya Manusia pada Era Informsi dan Kesejagatan (Globalisasi). Pidato Pengukuhan Guru Besar pada Fakultas Pendidikan Bahasa dan Seni IKIP Ujung Pandang.

Ismail. 2013. Pengembangan Model Pembelajaran IPA Terintegrasi Nilai Karakter di Sekolah Dasar. Proposal Disertasi Program Pascasarjana Universitas Negeri Makassar.

Ismail, Taufiq. 1998. Benarkah Kini Bangsa Kita Telah Rabun Membaca dan Lumpuh Menulis.

Jaya, Widuri. 2010. http://www.scribd.com/doc/366231 02/KTSP-SD-WIDURI-JAYA-TP2010-2011, diakses 23 Juli 2012.

Joyce, Bruce \& Weil, Marsha. 2000. Models of Teaching, Fifth Edition. Singapore: Allyn and Bacon.

McWhorter, Kathleen T. 1992. Effective and Flexible Reading: Third Edition. New York: HarperCollinsPublishers.

Megawangi, R. 2004. Pendidikan Karakter: Solusi Tepat untuk Membangun Bangsa. Jakarta: Indonesia Heritage Foundation.

Muji. 2011. Pengembangan Perangkat Pembelajaran Keterampilan Membaca Model Pembelajaran Kontekstual untuk Siswa S-1 PGSD FKIP UNEJ. Disertasi Program Pascasarjana Universitas Negeri Malang. 
Mulyasa. 2011. Manajemen Pendidikan Karakter. Jakarta: Bumi Aksara.

Nurhadi. 1987. Membaca Cepat dan Efektif. Bandung: Sinar Baru Bandung.

Oka, IGN. 1983. Pengantar Membaca dan Pembelajarannya. Surabaya: Usaha Nasional.

Pusat Bahasa. 2008. Kamus Bahasa Indonesia. Jakarta: Departemen Pendidikan Nasional.

Priyanti, Endah Tri. 2011. Pengembangan Bahan Ajar Membaca Kritis Berbasis Intervensi Responsif dengan Multimedia. Disertasi Program Pascasarjana Universitas Negeri Malang.

Rahim, Farida. 2003. Pembelajaran Membaca di Kelas IV Sekolah Dasar 08 di Kota Padang. Disertasi Program Pascasarjana Universitas Negeri Malang.

Rahim, Farida. 2011. Pembelajaran Membaca di Sekolah Dasar. Padang: Bumi Aksara.

Richards, Jack. Platt, John. Weber, Heidi. 1987. Longman Dictionary of Applied Linguistics. Hong Kong: Longman.

Rustono, W. 2010. Pengaruh Metode Pembelajaran Membaca dan Tingkat Kecerdasan terhadap Kemampuan Pemahaman Bacaan (Studi Eksperimen di SDN Dadaha I). Jurnal Saung Guru: Vol. I No. 2 Tahun 2010.

Shriver, Eunice Kennedy. 2007. What is Reading? National Institute of Child Health and Human Development:

http://www.nichd.nih.gov/health/to pics/reading.cfm, (diakses 10 Agustus 2012).
Smith, Frank. 1982. Writing dan the Writer. Londong: Heineman Educational Books.

Sudono, Anggani. 2000. Sumber Belajar dan Alat Permainan (untuk Pendidikan Usia Dini). Jakarta: Grasindo.

Sukmadinata, Nana Syaodih. 2005. Metode Penelitian Pendidikan. Bandung: Rosdakarya.

Supriyoko, Ki. 2011. Pendidikan Karakter. Membangun Delapan Karakter Emas Menuju Indonesia Bermartabat. Yogyakarta: Samudra Biru.

Syafi'ie, Imam. 1996. Terampil Berbahasa Indonesia I. Petunjuk Guru Bahasa Indonesia untuk SMA Kelas I. Jakarta: Balai Pustaka.

Syafi'ie, Imam. 1999. Pembelajaran Membaca di Kelas-Kelas Awal Sekolah Dasar. Pidato Pengukuhan Guru Besar dalam Bidang Ilmu Pembelajaran Bahasa Indonesia pada Fakultas Pendidikan Bahasa dan Seni disampaikan pada Sidang Terbuka Senat Universitas Negeri Malang, Malang, 7 Desember.

Tampubolon, D.P. (1986). Kemapuan Membaca, Teknik Membaca Efektif dan Efisien. Bandung: Angkasa.

Tolla, Ahmad. 1996. Kajian Pendekatan Komunikatif dalam Pembelajaran Bahasa Indonesia di Sekolah Menengah Umum di Kotamadya Ujung Pandang. Disertasi. Tidak Dipublikasikan Program Pascasarjana Institut Keguruan dan Ilmu Pendidikan Malang

Wibowo, Ari. 2008. Pengaruh Permainan Pada Perkembangan Anak. (on line: 
http://balitacerdas.com) diakses 23 Agustus 2012.

Widyamartaya, A. 1992. Seni Membaca untuk Studi. Yogyakarta: Kansius.

Wiryodijoyo, Suwaryo. 1989.

Membaca: Strategi, Pengantar, dan Tekniknya. Jakarta: Depdikbud.
Zuchdi, Darmiyati, dkk. 2007. Pendidikan Karakter melalui Pengembangan Keterampilan (Life Skills Development) dalam Kurikulum Persekolahan. http://eprints.uny.ac.id/1203/1/Dar miyati_Zuchdi.pdf. diakses 5 November 2012 